\title{
Life Cycle Carbon Footprint Assessments, Case Study of Malaysian Housing Sector
}

\author{
Syed Shujaa Safdar GARDEZI ${ }^{*}$, Nasir SHAFIQ ${ }^{2}$, Ishtiaq HASSAN³ ${ }^{3}$ M. Usman ARSHID ${ }^{4}$ \\ ${ }^{1,3}$ Department of Civil Engineering, Capital University of Science \& Technology (CUST), Islamabad \\ Expressway, Kahuta Road, Zone-V 44000 Islamabad, Pakistan \\ ${ }^{2}$ Department of Civil and Environmental Engineering, Universiti Teknologi PETRONAS, 32610 Seri \\ Iskandar, Perak Darul Ridzuan, Malaysia \\ ${ }^{4}$ Department of Civil Engineering, University of Engineering and Technology, \\ Taxila, Pakistan
}

\begin{abstract}
The ever-increasing concentration of Carbon footprint into the environment has drastically changed the climatic conditions. Among many anthropogenic activities, the housing sector remains one of the major contributors. However, a complete assessment of these environmental impacts throughout the life cycle still remains an area of concern. Most of the study does not assess the impacts by each phase of lifecycle. The current work presents a complete approach for carbon footprint assessment including planning, construction, operational, maintenance and dismantling \& dispose-off phase. Life Cycle Assessment (LCA) with boundary limitations of 'cradle to grave' was adopted. Thirteen housing units were selected as case study. These included detached, semi-detached and terraced types of construction. Selected units were developed in a virtual environment using Building Information Modeling (BIM). The study observed the average contribution range from 1.48 tons- $\mathrm{CO}_{2} / \mathrm{yr}$ to 2.85 tons- $\mathrm{CO}_{2} / \mathrm{yr}$. On individual basis, the execution phase dominated the five phases with almost $43 \%$. The operational phase shared $39 \%$ followed by maintenance $(15 \%)$, dismantling $\&$ dispose-off $(1.8 \%)$ and planning at the last $(1.5 \%)$. The categorization of environmental impact into embodied and operational carbon footprint observed the embodied part in dominance. A strong positive relationship between the area of housing units and resulting carbon impact was also observed. The work presents one of few environmental studies for a tropical housing sector assessing complete life cycle. The study provides a vital guideline to the designers for ensuring a sustainable environment by assessing and opting less carbon intensive options at early stage of planning and design.
\end{abstract}

Keywords - Building Information Modelling; $\mathrm{CO}_{2}$; embodied carbon; Life Cycle Assessment; operational carbon

\section{INTRODUCTION}

The increasing concentration of Carbon dioxide $\left(\mathrm{CO}_{2}\right)$ in particular, due to anthropogenic activities has seriously transformed the global climate system as compared to pre-industrial times [1]. An yearly addition of almost 30 billion tons of $\mathrm{CO}_{2}$ into atmosphere is expected to cause a rise in the sea level by $10-20 \mathrm{~cm}$ during the $20^{\text {th }}$ century with a $30 \%$ increase in global $\mathrm{CO}_{2}$ emissions and a temperature rise by 0.3 to $0.68^{\circ} \mathrm{C}$ [2]-[4]. The construction sector remains a basic pillar for many economies. Despite its vital role, it is not considered an environmentally friendly industry. Significant energy consumption and corresponding

* Corresponding author.

E-mail address: dr.shujaasafdar@cust.edu.pk 
Greenhouse Gas (GHG) emissions by this sector has been reported [5], [6]. Besides utilization of $60 \%$ raw materials extracted from the Earth, it causes $50 \%$ of all atmospheric $\mathrm{CO}_{2}$, during raw materials transformation [7]. Presently, various largest sources of carbon footprint at global level relate to this sector [8]. In US, it remained the third largest contributor in carbon footprint sharing $38 \%$ [9] and $39 \%$ [10]. For EU-15, it consumes $46 \%$ of the total energy usage and generates $46 \%$ of $\mathrm{CO}_{2}$ with $40 \%$ of all man-made waste [11], [12]. Ireland observed $11.7 \%$ (13.81 $\mathrm{Mt} \mathrm{CO}_{2}$ eq) [13], [14]. For Spain, Germany, and France, it represented $40 \%, 23 \%$ and $22 \%$ share of construction in their overall carbon emission respectively [15]. In industrialized countries, a consumption of $40 \%$ of primary energy use and $36 \%$ of energy related $\mathrm{CO}_{2}$ has been recorded [16], [17]. For China it accounts $25 \%$ of its national carbon emissions [18]. For Korea, the construction materials contribute $14.1 \%$ in an overall share $34 \%$ in industrial sector [12]. Similarly, Singaporean construction emitted $16 \%$ in overall emissions and ranked $3^{\text {rd }}$ largest source [10], [19].

Based upon the consumption of more than $40 \%$ of global energy and generating $30 \%$ greenhouse gas emissions globally, buildings are considered a major player in environmental degradation [20]. 30-40\% of energy utilization along with $33 \%$ of global GHGs and almost $20 \%$ of the fuel for global material production industry had been attributed to building sector [21]-[24]. According to Nematchoua and Reiter [25], 40\% of total energy usage along with $24 \%$ of $\mathrm{CO}_{2}$ emissions comes from buildings worldwide as result of energy usage. In Australia, buildings (residential and non-residential) use almost $7.6 \%$ of overall primary energy and approximately result $6.0 \%$ of total GHG (equivalent) emissions in Australia [26]. Rosello-Batle et al. [15] reported $30 \%$ greenhouse gas $\mathrm{CO}_{2}$ emissions in Spain. About $29 \%$ of total secondary energy use with nearly $27 \%$ of total GHG emissions has been reported for Canada [27], [28]. The Turkish residential sector consumes $32 \%$ of its total energy [20]. $32.6 \%$ of final energy consumption has been reported for Iranian building sector [29].

The construction sector is striving hard for sustainable solutions. Life Cycle Assessment (LCA) has been implemented as, both, methodology and research scope in numerous studies with various models for the fields of energy, environment, social politics, and economy [30]. Its application in the building has observed multidimensional utilization as management tool [9], [31]-[34], evaluation system [35], method/methodology [36], [37] and approach for environmental impacts [16]. However, a generic policy development for building environment assessment has been seriously challenged by varying characteristics including location, size and construction material etc. [38]. Most of previous LCA studies can be limited on the basis of different variables involved. Based upon the experience of 'usage' phase for Mexican housing, Arvizu-Pina, et al. [39] also stressed on whole life cycle approach in sustainability concerns at strategic level. Similarly, Nasab, et al. [40] has also recommended to include other phases of life cycle including operations, maintenance, and demolition to achieve a complete life cycle assessment. So, a comprehensive approach based on whole life cycle still remains the fundamental to set the criteria and exploit the opportunities of achieving the required goal of sustainability [41]. With $40 \%$ expected increase in population of 2005 and $60 \%$ urbanization by 2030 [42], a massive global construction activity would be required. Although various environmental assessment (BEA) concepts have developed, but practically, the present approaches limit to generic environmental performance evaluations of building rather than actual carbon footprints. The current lack of systematic auditing and benchmarking the lifecycle carbon emissions encourage to explore further for sustainable endeavours [43]. 


\section{METHODOLOGY}

The main source of primary data was acquired through preliminary survey of the relevant construction organization working in housing sector. The secondary data acquired from construction firms included drawings, specifications, bill of quantities along with published literature on GHG emissions relevant to construction sector.

\subsection{Selection of Case studies and Virtual Modelling}

Housing units were selected as case studies adopting a specific criterion governed by following conditions to exclude insignificant differences in carbon footprint contributions. After fulfilling, thirteen (13) housing units, Table 1, were selected.

1. The area between two different units in same category should not be less than $100 \mathrm{sft}$;

2. The difference of one size, either length or width, between two options in same category should not be less than $5 \mathrm{ft}$;

3. Units shall be limited to single and double story type of housing;

4. The units existing in actual or planned construction in conventional Malaysian housing sector to be considered only.

Table 1. Details of Selected Case Studies

\begin{tabular}{llllllll}
\hline Model ID & Area & Story & Type & Model ID & Area & Story & Type \\
\hline $\mathrm{H}-01$ & 1625.00 & Single & Semi-detached & $\mathrm{H}-08$ & 2625.00 & Single & Semi-Detached \\
$\mathrm{H}-02$ & 2925.00 & Single & Detached & $\mathrm{H}-09$ & 3870.83 & Double & Terraced \\
$\mathrm{H}-03$ & 2800.00 & Single & Detached & $\mathrm{H}-10$ & 3414.90 & Double & Terraced \\
$\mathrm{H}-04$ & 4401.36 & Double & Terraced & $\mathrm{H}-11$ & 2965.50 & Double & Terraced \\
$\mathrm{H}-05$ & 3941.68 & Double & Semi-Detached & $\mathrm{H}-12$ & 3672.01 & Double & Terraced \\
$\mathrm{H}-06$ & 3026.66 & Double & Terraced & $\mathrm{H}-13$ & 3893.75 & Double & Terraced \\
$\mathrm{H}-07$ & 4000.00 & Single & Detached & & & & \\
\hline
\end{tabular}

Building Information modelling (BIM) process developed case studies in virtual environment. According to National Building Information Modelling Standards (NBIMS), BIM is 'the digital representation of physical and functional characteristics of a facility' [44]. The quantification of carbon footprint sources was achieved by $3 \mathrm{D}$ virtual prototyping whereas regression tools helped in empirical modelling. In current work, 3D parametric models up to LOD-300 (construction drawings) were developed.

\subsection{Life Cycle Assessment (LCA)}

According to International Organization for Standardization (ISO), Life cycle assessment (LCA) is defined as 'a technique to assess the environmental performance of a product, process or activity from cradle to grave, i.e. extraction to its final disposal' [45]. Life cycle assessment (LCA) was divided into five phases; planning \& design (P\&D), construction, operation, maintenance and end-of-life (EOL). Critical literature review and the consultation of industry experts guided to highlight the sources of $\mathrm{CO}_{2}$ emissions. The total carbon footprint for the housing project is the summation of contributions from these phases, mathematically by Eq. (1).

$$
\sum \mathrm{CO}_{2(\mathrm{LCA})}=\sum \mathrm{CO}_{2(\mathrm{P} \& \mathrm{D})}+\sum \mathrm{CO}_{2(\mathrm{exe})}+\sum \mathrm{CO}_{2(\text { oper })}+\sum \mathrm{CO}_{2(\text { maint })}+\sum \mathrm{CO}_{2(\mathrm{~d} \& \mathrm{~d})}
$$

At the moment, no clear standard guidelines were available to quantify the $\mathrm{CO}_{2}$ emissions generated form P\&D. A questionnaire was developed to achieve the sources which were 
categorized into three main heads; travel to office facility, accessories utilized for works and operation of office facility. The cumulative sum of each identified factor provided with the contribution of total carbon footprint for this phase.

For construction phase, the quantities of materials were extracted from virtual models. The quantities of major materials form virtual BIM models, the bill of quantities (B.O.Qs) and the original estimates were cross checked using Triangulation method. The carbon footprint potential was assessed using the Inventory of Carbon and Energy (ICE) [46] and Guidelines to Department for Environment, Food \& Rural Affairs (DEFRA) [47]. The embodied carbon for each of material was calculated by multiplying the weights with respective carbon emission factors. For transportation, a carrier vehicle with a standard load carrying capacity (6 tons), normally used in Malaysia, was considered with a radial distance of $50 \mathrm{~km}$ for the material availability [48].

The electricity is one of major source of energy to run day to day operations throughout the design life. The provision of equipment was based on the design features of facilities according to the income level and house hold report by department of statistics [49]. The daily time of operation followed the guidelines and recommendation of Tenaga Nasional Berhad, Malaysia. The operational carbon footprint was calculated utilizing carbon emission factors; based on electricity generation mix reported in Malaysian energy statics handbook 2014 [50], and International energy Agency (IEA) statistics report ' $\mathrm{CO}_{2}$ emissions from fuel combustion - edition 2015 [51]'.

A service life with an interval of 10 years each for a range of 50 to 100 years, was considered for maintenance phase. The replacement cycles were calculated based on the design life with the respective service life, Table 2 . The total recurrent carbon footprint was achieved from manufacturing and transportation to the construction facility for replacement.

TABle 2. Service Life AND RePlacement Details During Design Phase

\begin{tabular}{lll}
\hline Description of Material & Service Life & Source \\
\hline Ceramic Tiles & 30 & {$[52]$} \\
False Ceiling & 10 & {$[53]$} \\
Paint & 10 & \\
Plaster & 30 & \\
PVC Door Panels & 10 & \\
Wood & 25 & {$[52]$} \\
Mild Steel & 40 & {$[54]$} \\
Roof Tiles & 25 & \\
\hline
\end{tabular}

The involvements of mechanical equipment in dismantling and dispose-off operations contributed in this last phase, EOL. However, the quantum of such emissions relied on the type of equipment, duration of its operation, type of fuel and distance for disposal, a recycling unit for some of materials or waste pit. The dismantling operation was based on standard equipment locally available in construction market. Diesel operated Excavator/Loader (M318) and Dump truck (6 tons load carrying capacity) have been considered with a fuel consumption rate of 3.5-5.0 gallons/hr and $6 \mathrm{~km} / \mathrm{litre}$ respectively. The data pertinent to the duration for dismantling operation projects was based upon the feedback from the construction industry experts and professional organizations involved in such operations for housing stocks. Table 3 summarizes the carbon footprint assessment models for each of the phase. 
TABle 3. CARbon FootPrint AsSESSMENT Models AdOPTED FOR CALCULATION OF $\mathrm{CO}_{2}$ EMISSIONS FROM EACH PHASE

\begin{tabular}{|c|c|c|}
\hline Phase & Carbon Footprint Assessment Model & Explanations \\
\hline $\begin{array}{l}\text { Planning } \\
\text { and Design } \\
\text { Phase }\end{array}$ & $\begin{array}{l}\sum_{i=0}^{n} \mathrm{CO}_{2(\mathrm{P} \& \mathrm{D})}=\sum C O_{2(\text { manower })}+\sum C O_{2(\text { eqpts })}+\sum C O_{2 \text { (facility })} \\
\sum C O_{2(\text { manower })}=d_{(\mathrm{avg})} \cdot F_{(\text {lit })} \cdot E_{(\mathrm{f})} \\
\sum C O_{2(\text { eqpts })}=N \cdot E_{(\mathrm{kWh})} \cdot E_{(\mathrm{e})} \\
\sum C O_{2 \text { (facility })}=N \cdot E_{(\mathrm{kWh})} \cdot E_{(\mathrm{e})}\end{array}$ & $\begin{array}{l}n=\text { No. of housing units, } \\
d_{\text {(avg) }}=\text { Average distance } \\
\text { travelled from office to home, } \\
F_{\text {(lit) }}=\text { Fuel consumption for } \\
\text { distance travelled, } \\
E_{(\mathrm{f})}=\text { Emission factor / unit } \\
\text { fuel consumed, } \\
N=\text { No. of equipment in } \\
\text { operation, } \\
E_{(\mathrm{kWh})}=\text { Energy consumption } \\
\text { in kWh per unit of equipment } \\
\text { in operation, } \\
E_{(\mathrm{e})}=\text { Emission factor / unit } \\
\text { electricity consumed. }\end{array}$ \\
\hline $\begin{array}{l}\text { Construction } \\
\text { Phase }\end{array}$ & $\begin{array}{l}\sum_{i=0}^{n} C O_{2(\text { exe })}=\sum C O_{2(\text { materials })}+\sum C O_{2 \text { (transport) }} \\
\sum C O_{2(\text { materials })}=Q t y \cdot E_{(\mathrm{f})} \\
\sum C O_{2 \text { (transport) }}=N_{(\text {trips })} \cdot d_{(\text {avg })} \cdot F_{(\text {lit })}\end{array}$ & $\begin{array}{l}d_{\text {(avg) }}=\text { Average distance } \\
\text { travelled for trip, } \\
F_{\text {(lit) }}=\text { Fuel consumption for } \\
\text { distance travelled, } \\
E_{\text {(f) }}=\text { Emission factor / unit } \\
\text { fuel consumed, } \\
N_{\text {(trips) }}=\text { No. of trips, } \\
Q t y=\text { Quantity of respective } \\
\text { materials. }\end{array}$ \\
\hline $\begin{array}{l}\text { Operational } \\
\text { Phase }\end{array}$ & $\sum_{i=0}^{n} C O_{2(\mathrm{oper})}=L_{\mathrm{des}}\left\{N_{\mathrm{eqpt}} \cdot P w r \cdot O P_{\mathrm{hrs}} \cdot N O_{\text {days }} \cdot E_{(\mathrm{f})}\right\}$ & $\begin{array}{l}L_{\text {des }}=\text { Design life, } \\
N_{\text {eqpt }}=\text { No. of Equipment, } \\
P w r=\text { Power rating, } \\
O P_{\text {hrs }}=\text { Operating hours, } \\
N O_{\text {days }}=\text { No. of operating } \\
\text { days, } \\
E_{(\mathrm{f})}=\text { Emission factor } / \text { unit } \\
\text { fuel consumed. }\end{array}$ \\
\hline $\begin{array}{l}\text { Maintenance } \\
\text { Phase }\end{array}$ & $\begin{array}{l}\sum_{i=0}^{n} \mathrm{CO}_{2 \text { (maint) }}=\sum C O_{2 \text { (materials) }}+\sum C O_{2 \text { (transport) }} \\
\sum C O_{2 \text { (materials) }}=\frac{L_{\mathrm{des}}}{L_{\mathrm{ser}}} \cdot Q t y \cdot E_{(\mathrm{f})} \\
\sum C O_{2 \text { (transport) }}=N_{(\text {rep })} \cdot N_{(\text {trips })} \cdot d_{(\text {avg })} \cdot F_{(\text {lit })} \cdot E_{(\mathrm{f})}\end{array}$ & $\begin{array}{l}N=\text { frequency of } \\
\text { replacements, } \\
L_{\text {des }}=\text { Design life of facility, } \\
L_{\text {ser }}=\text { Service life of materials, } \\
d_{\text {(avg) }}=\text { Average distance } \\
\text { travelled for trip, } \\
F_{\text {(lit) }}=\text { Fuel consumption for } \\
\text { distance travelled, } \\
E_{\text {(f) }}=\text { Emission factor } / \text { unit } \\
\text { fuel consumed, } \\
N_{\text {(trips) }}=\text { Number of trips, } \\
Q t y=\text { Quantity of respective } \\
\text { materials, } \\
N_{\text {(rep) }}=\text { Number of } \\
\text { replacements }=L_{\text {des }} / L_{\text {ser. }} .\end{array}$ \\
\hline $\begin{array}{l}\text { Dismantling } \\
\text { and } \\
\text { Dispose-off } \\
\text { Phase }\end{array}$ & $\begin{array}{l}\sum_{i=0}^{n} \mathrm{CO}_{2(\mathrm{~d} \& \mathrm{~d})}=\sum C O_{2(\mathrm{dism})}+\sum C O_{2(\text { dispose-off })} \\
\sum C O_{2(\mathrm{dism})}=N_{(\mathrm{days})} \cdot \mathrm{Hrs}_{(\mathrm{opr})} \cdot F_{(\mathrm{lit})} \cdot E_{(\mathrm{f})} \\
\sum C O_{2(\text { dispose-off })}=N_{(\text {trips })} \cdot d_{(\mathrm{avg})} \cdot F_{(\text {lit })} \cdot E_{(\mathrm{f})}\end{array}$ & $\begin{array}{l}N_{\text {(days) }}=\text { Number of days of } \\
\text { operation, } \\
H r s_{(\text {opr })}=\text { Number of average } \\
\text { operating hours in a day, } \\
E_{(\mathrm{f})}=\text { Emission factor / unit } \\
\text { fuel consumed, } \\
N_{\text {(trips) }}=\text { Number of trips, } \\
d_{\text {(avg) }}=\text { Average distance } \\
\text { travelled for disposal trip, } \\
F_{(\text {lit) }}=\text { Fuel consumption for } \\
\text { distance travelled. }\end{array}$ \\
\hline
\end{tabular}




\section{RESUlts AND DiscusSiONS}

The life cycle was divided into five sections according to the different phases opted. For P\&D phase, a summary comprising contribution of housing units was formulated in accordance with the main heads through questionnaire. Usually, this phase varies up to six months. The reliability test was performed and found consistent with value of 0.86 , higher than 0.70 . The total contribution from P\&D phase remained from 2200 to $3600 \mathrm{~kg}-\mathrm{CO}_{2}$ with standard deviation of $16.5 \%$ and variation of $63 \%$ in the carbon footprint. The intensity of refrigerator and $\mathrm{AC}$ was also observed to dominate all the sources involved. Fig. 1 details the contribution relevant to type of housing units based upon respective contributions. The results show that the contribution of traveling ranged 450 to $1000 \mathrm{~kg}-\mathrm{CO}_{2}$, office operation 1500 to $2400 \mathrm{~kg}-\mathrm{CO}_{2}$ and equipment 215 to $390 \mathrm{~kg}-\mathrm{CO}_{2}$. On average, the three heads shared $67 \%$, $23 \%$ and $10 \%$ contributions respectively. Comparison observed the operation of the office facility as the top main head followed by travel to office facility and accessories.

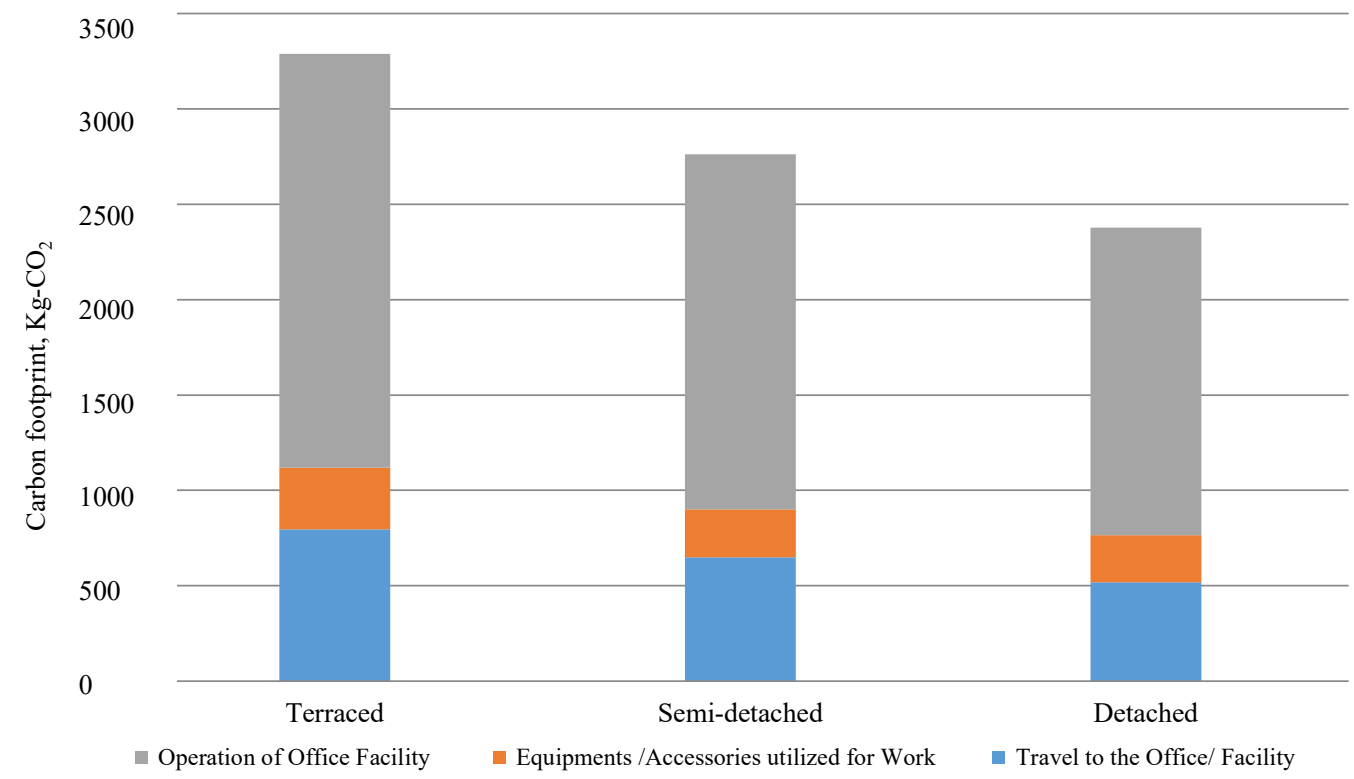

Fig. 1. Head wise contribution of carbon footprint during the P\&D phase.

The total contribution from construction phase ranged from 50 tons-CO2 to 103 tons-CO2. The bricks, concrete, steel rebar and mild steel were top four contributors which, on average, contributed almost $85 \%$ of the overall emissions. A variation 24 tons- $\mathrm{CO}_{2}$ was observed in case of bricks, 22 tons- $\mathrm{CO}_{2}$ for concrete, 11.40 tons- $\mathrm{CO}_{2}$ for steel and 11.60 tons- $\mathrm{CO}_{2}$ for mild steel. The materials contribution trend behaved almost uniformly, Fig. 2. However, the terraced housing units resulted in 88 tons $-\mathrm{CO}_{2}, 24 \%$ higher than detached and $32 \%$ than that of semi-detached type. 
Terraced

Semi-detached

Detached
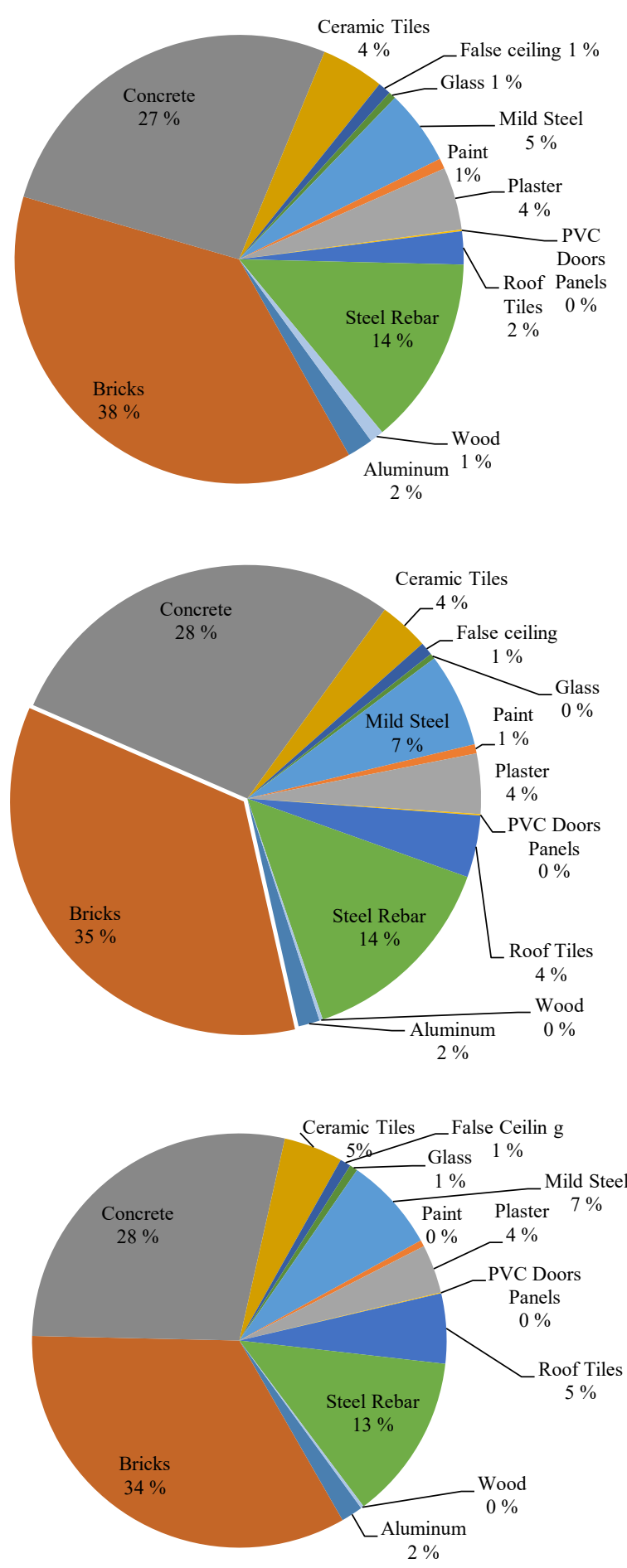

Fig. 2. Category wise percentage share of material in total $\mathrm{CO}_{2}$. 
For the current study, the service life varied from 50-100 years, with an interval of 10 years, opted in compliance with previous studies on the environmental impact for housing facilities. The contribution range has been elaborated in Fig. 3.

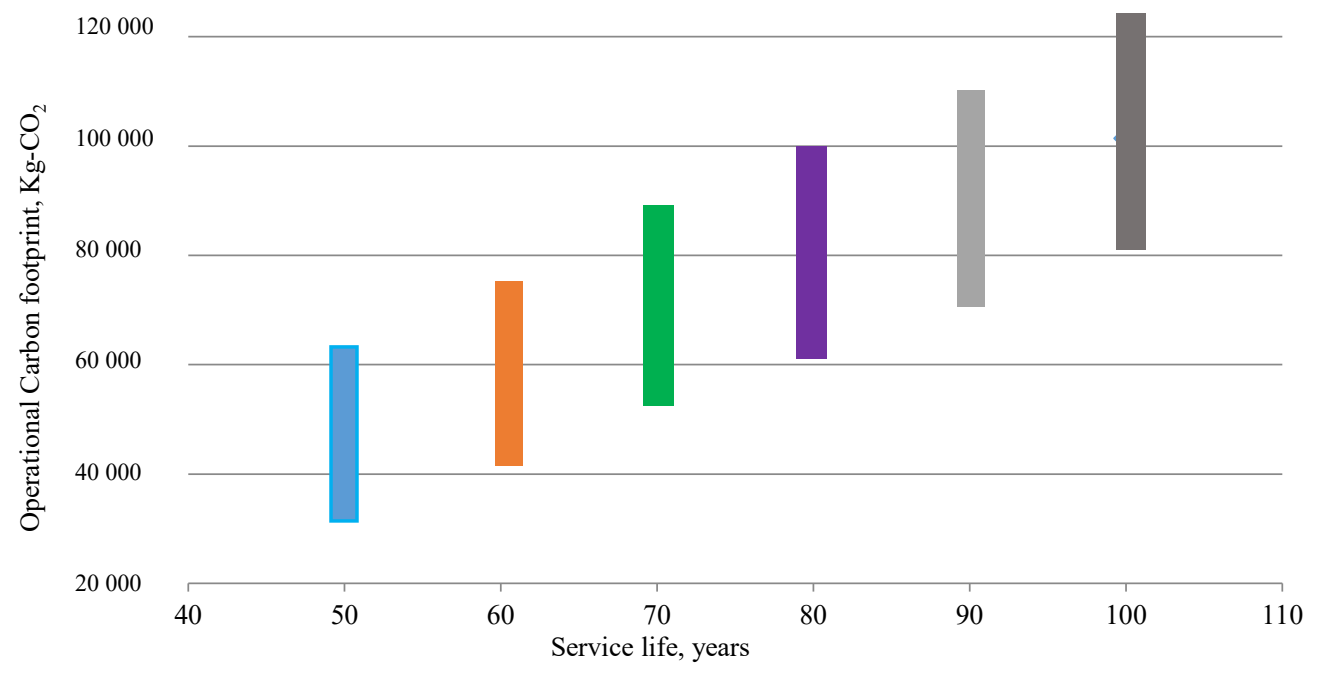

Fig. 3. Operational carbon footprint $\left(\mathrm{kg}-\mathrm{CO}_{2}\right), 50-100$ years of service life.

The operational carbon impact was further categorized into six major activities, Table 4. The refrigeration and air conditioning were the top two categories of energy utilization with an average share of more than $75 \%$ in each of the case. On average, the terraced type generated less amount of carbon footprint as compared to the semi-detached and detached. The attribute of income level of residents was a vital factor. According to house hold statistics survey 2014, the distribution of housing sector is based upon the income levels. The terraced type units accommodate the low-income level whereas the other two types target the middleand upper-income levels respectively. As per survey, $44 \%$ of the residents of middle- and higher-income category utilized the air conditioning facility. The statistics observed the upper level, top $20 \%$, on average spends almost $15 \%$ of house-hold income on electricity, gas and air conditioning utilities. Similarly, the middle level, also known as middle $40 \%$, spends $9.50 \%$ for these facilities. However, the bottom $40 \%$ or low-income level spends only $3 \%$ to $5 \%$ of their household income on such facilitation.

TABLE 4. OPERATIONAL CARBON FOOTPRINT StATISTICS

\begin{tabular}{lllllll}
\hline \multirow{2}{*}{ Description } & \multicolumn{3}{l}{ Avg. contribution, \% } & \multicolumn{3}{c}{ Standard Deviation } \\
\cline { 2 - 7 } & Terraced & Semi-detached & Detached & Terraced & Semi-detached & Detached \\
\hline Air Conditioning/Fan & 11.26 & 33.41 & 37.91 & 0.63 & 0.85 & 3.86 \\
Cleaning & 10.63 & 6.81 & 7.55 & 0.17 & 2.07 & 0.45 \\
Cooking & 4.09 & 2.76 & 2.90 & 0.07 & 0.55 & 0.17 \\
Lighting & 5.59 & 3.05 & 3.05 & 0.76 & 1.73 & 0.32 \\
Refrigeration & 64.26 & 50.38 & 45.63 & 1.04 & 3.86 & 2.74 \\
Entertainment & 4.17 & 3.59 & 2.96 & 0.07 & 0.79 & 0.18 \\
\hline
\end{tabular}


For maintenance phase, roof tiles $(23 \%)$ were the top contributing material followed by plaster $(22 \%)$, ceramic tiles $(21.50 \%)$, false ceiling $(16.50 \%)$ and paint $(10 \%)$, with individual contribution more than $10 \%$. The share of PVC door panels and wood remained almost $2 \%$ or less, Table 5 .

\section{TABLE 5. INDIVIDUAL CONTRIBUTION TREND FOR RECURRENT CARBON FOOTPRINT}

\begin{tabular}{lllllll}
\hline \multirow{2}{*}{ Description of Material } & \multicolumn{5}{c}{ Percentage Contribution for service life opted } \\
\cline { 2 - 7 } & $\mathbf{5 0}$ & $\mathbf{6 0}$ & $\mathbf{7 0}$ & $\mathbf{8 0}$ & $\mathbf{9 0}$ & $\mathbf{1 0 0}$ \\
\hline Ceramic Tiles & 21.71 & 17.33 & 24.20 & 21.21 & 21.21 & 23.99 \\
False Ceiling & 18.42 & 18.29 & 15.49 & 15.77 & 15.77 & 15.33 \\
Mild Steel & 5.57 & 4.46 & 3.33 & 2.90 & 2.90 & 4.28 \\
Paint & 11.40 & 11.32 & 9.57 & 9.76 & 9.76 & 9.48 \\
Plaster & 21.92 & 17.38 & 24.53 & 21.40 & 21.40 & 24.29 \\
PVC Doors Panels & 1.99 & 1.98 & 1.68 & 1.71 & 1.71 & 1.66 \\
Roof Tiles & 18.01 & 27.69 & 20.10 & 25.82 & 25.82 & 19.88 \\
Wood & 0.98 & 1.53 & 1.10 & 1.43 & 1.43 & 1.09 \\
\hline
\end{tabular}

For each of life span adopted, the top four materials contributed more than $80 \%$. However, the average contribution depicted a mix trend. The variation in service life of different materials was the main reason of such mix trend. The terraced housing units contributed the most as compared to the semi-detached and detached one, Fig. 4.

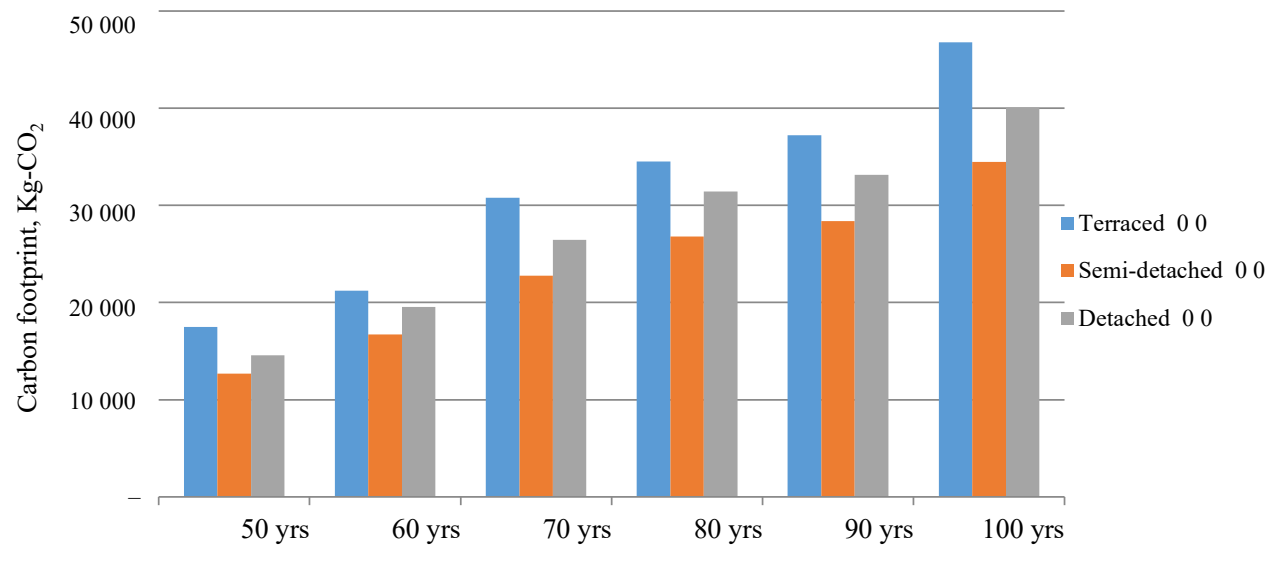

Fig. 4. Category wise recurrent $\mathrm{CO}_{2}$ contribution, 50-100 years span

The $1^{\text {st }}$ span of 10 years (50 to 60$)$ observed $26 \%$ increase, $2^{\text {nd }}$ span (60 to $70 \mathrm{yrs}$.) $41 \%$, $3^{\text {rd }} \operatorname{span}\left(70\right.$ to $80 \mathrm{yrs}$.) $15 \%, 4^{\text {th }}$ span ( 80 to 90 yrs.) $7 \%$ and the last span (90 to $100 \mathrm{yrs}$.) observed an increase of $24 \%$. The quantity of materials was the main source of these high contributions. The terraced housing comprised of double story height, the semi-detached both single and double story whereas the detached limit to single story height only. The height parameter directly contributed in higher carbon footprint. Transport activity also observed similar trend for contributions. The total carbon footprint from EOL remained 2.3 tons $-\mathrm{CO}_{2}$ to 3.85 tons $-\mathrm{CO}_{2}$ with $64 \%$ variation. The dismantling dominated the contributions over the dispose-off operation, Fig. 5. 


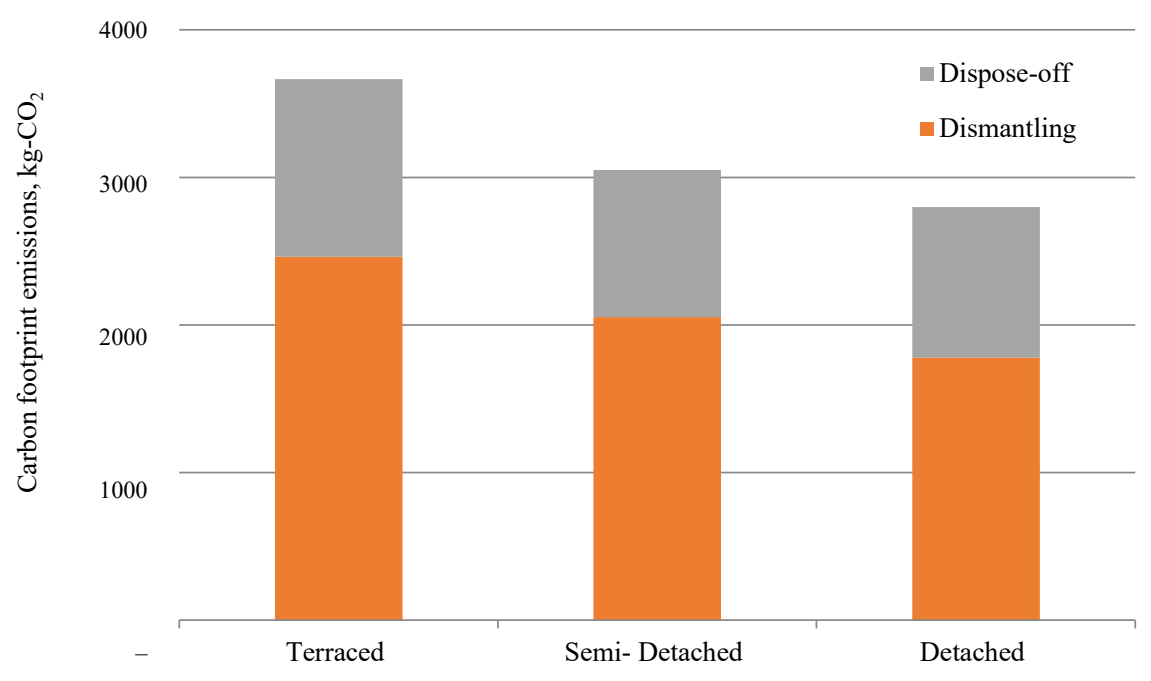

Fig. 5. Total carbon footprint from D \& D.

On average, the dismantling operation shared $66 \%$ of the contributions and varied over a range of $60 \%$ to $71 \%$. In case of dismantling activity, detached housing observed lowest contributor with an average of 1.8 tons. This emission was $15 \%$ lower than semi-detached and $38 \%$ less than terraced type.

The activity wise analysis observed that dismantling of the terraced units resulted almost $20 \%$ and $38 \%$ more carbon than the other types of construction respectively. Similarly, in case of disposal, semi-detached and detached housing units resulted in a $21 \%$ and $18 \%$ lesser content of emissions than that of terraced ones. With lesser average quantity of materials, semi-detached units were the lowest in resulting $\mathrm{CO}_{2}$ content from the dispose-off activity. The ease of access for equipment operation was one factor affecting the carbon level with direct impact on movement, operational time and fuel consumption. On overall basis, the terraced housing units dominated this phase followed by the semi-detached and detached type construction. These contributions were higher by $20 \%$ and $30 \%$ as compared to semidetached and detached housing units respectively. After detailing the life cycle inventory (LCI), the total carbon footprint for the housing project was the summation of contributions, Eq. (1). Based upon the average contribution for each of the phase, the following phase wise range were observed.

$\begin{array}{lll}2.20 \text { tons }-\mathrm{CO}_{2} & <\text { Planning \& Design }(\mathrm{P} \& D) & >3.60 \text { tons- } \mathrm{CO}_{2} \\ 50.0 \text { tons }-\mathrm{CO}_{2} & <\text { Execution /Construction } & >103.0 \text { tons }-\mathrm{CO}_{2} \\ 35.0 \text { tons }-\mathrm{CO}_{2} & <\text { Operation/ Usage } & >122.0 \text { tons }-\mathrm{CO}_{2} \\ 10.0 \text { tons }-\mathrm{CO}_{2} & <\text { Maintenance } & >58.0 \text { tons- }-\mathrm{CO}_{2} \\ 2.3 \text { tons }-\mathrm{CO}_{2} & <\text { Dismantling \& Dispose-off } & >3.90 \text { tons- }-\mathrm{CO}_{2}\end{array}$

The environmental impact resulted in a standard deviation of $12 \%, 11 \%, 11 \%, 10.5 \%$, $10 \%$ and $10 \%$ respectively. The average percentage share of each phase for each case study, Fig. 6. 


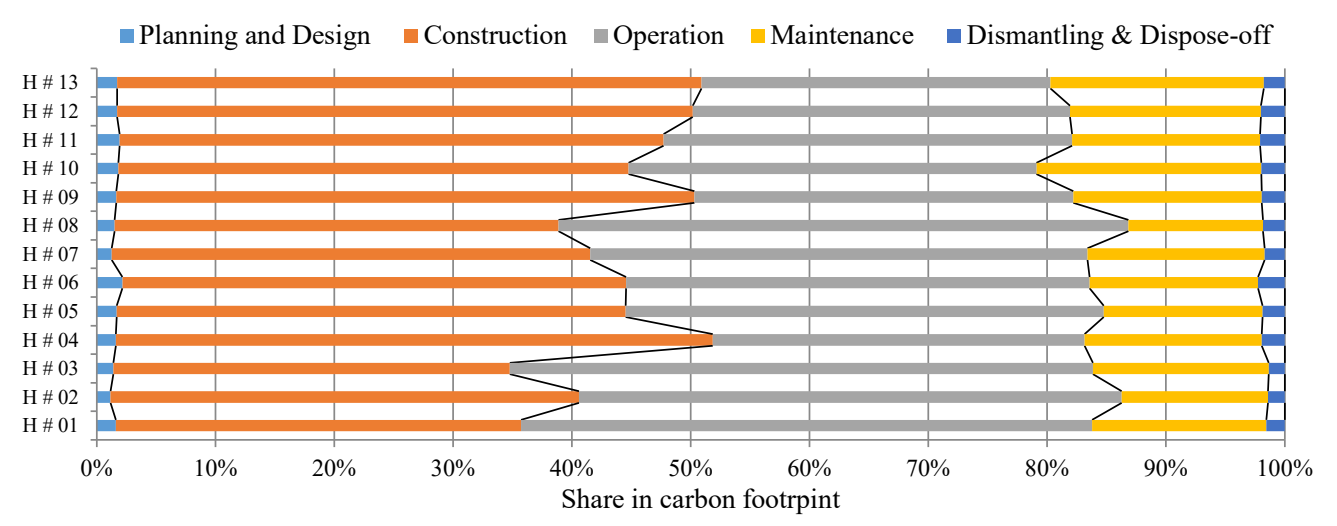

Fig. 6. Phase wise percentage contribution trend on individual basis.

The construction and operational phase remained the top two contributors with more than $80 \%$ share. On average, the construction phase dominated $(42.7 \%)$ followed by operational phase $(39 \%)$, maintenance $(15 \%)$, EOL $(1.8 \%)$ and P\&D (1.5\%). However, the category wise assessment on the basis of type of construction does not follow the average trend. For life scenario 50, 60 and 70 years, the construction phase dominated the life cycle. However, beyond 70 years, the operational phase appeared to be dominant. Both phases achieved a transitional point by intersecting almost at 80 years. The maintenance phase observed a gradual increase whereas a constant uniform trend has been achieved for the P\&D and EOL phases, Fig. 7.

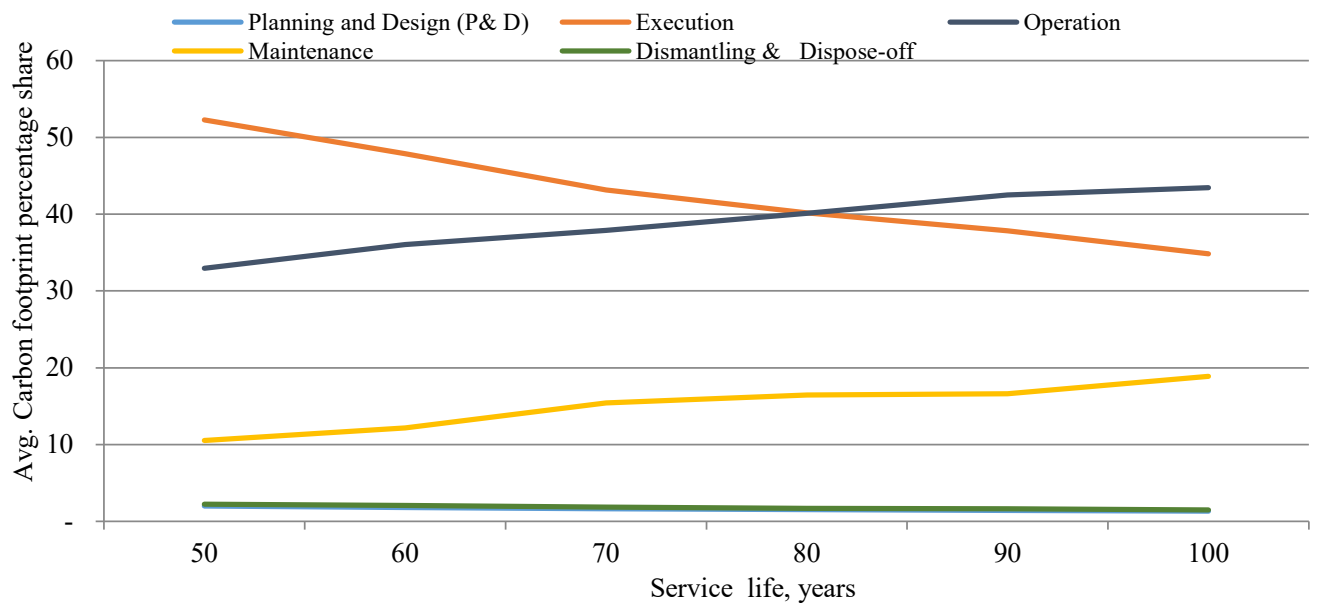

Fig.7. Phase wise variations in average contribution trend.

The category wise carbon footprint contributions throughout the phases of life cycle highlighted certain variations from the overall trend. Interestingly, the construction and operational phases depict a noticeable variation with respect to time, Fig. 8 . The construction phase dominated the whole life cycle in case of terraced type housing with a possible point of intersection with the operational phase just after the 100 years. However, in case of semidetached and detached housings, the point of intersection was achieved after 60 years. 
In other words, after this point, the operational phase contribution remained dominant among all phases. A fairly consistent pattern for P\&D and EOL was observed. As far maintenance was concerned, the trend remained the similar but observed gradual increase in carbon footprint. One of the important factors observed was that even as the area varied by $170 \%$ $(1625 \mathrm{sft}$ to $4400 \mathrm{sft})$, the total carbon footprint, on average, varied by $50 \%$ for 50 years of time span.
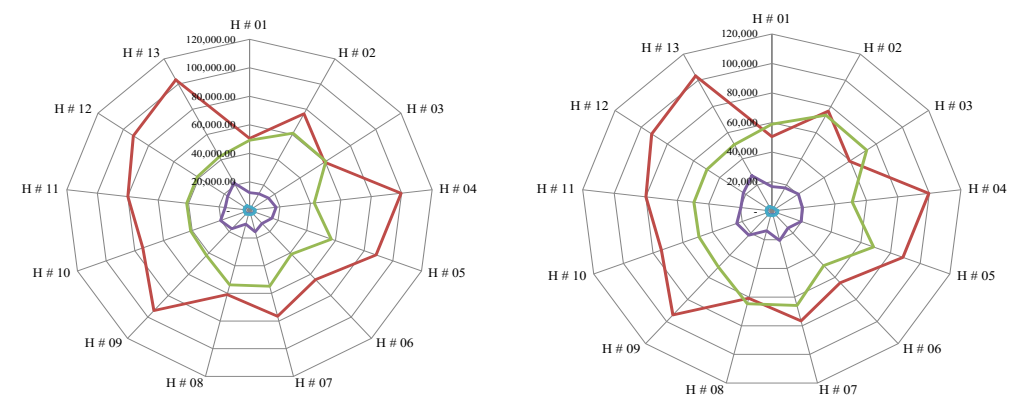

Design life, 50 years

Design life, 60 years
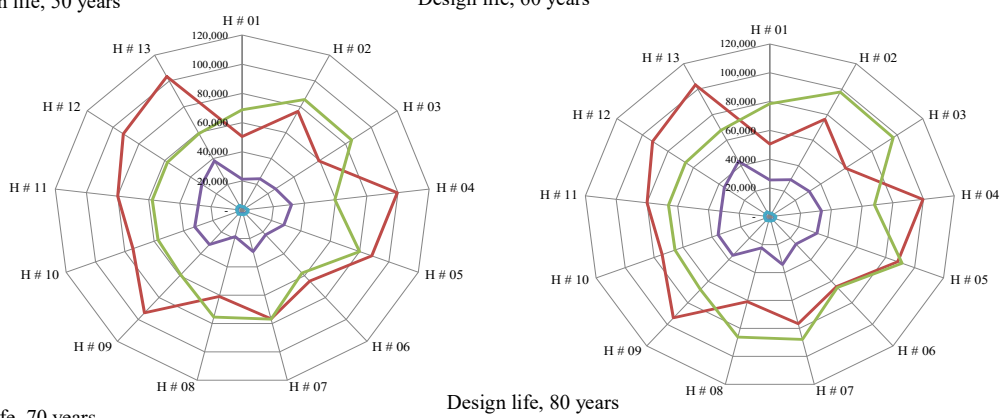

Design life, 70 years

Design life, 80 years
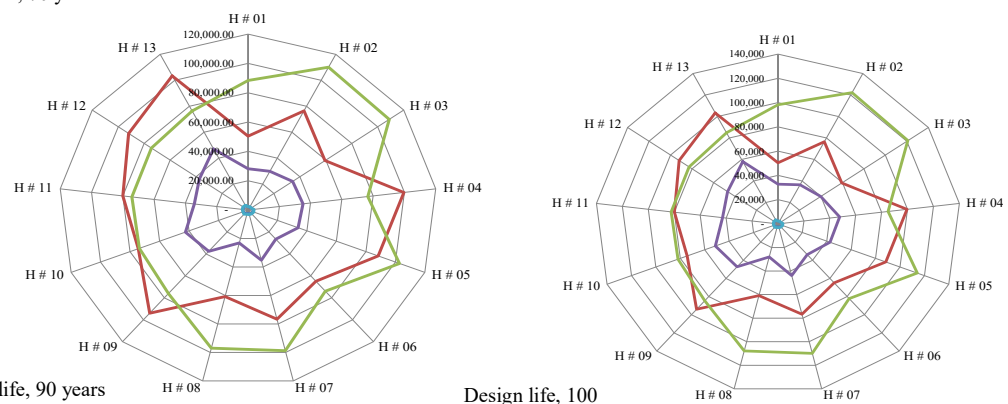

Design life, 90 year

Design life, 100 Dismantling \& dispose off

Fig. 8. Variation in contribution trend of each phase w. r. time.

\section{Conclusions}

The current work assessed the carbon footprint throughout the life cycle for housing sector. Life cycle assessment (LCA) was adopted with boundary limitations of cradle to grave. Five 
phases were adopted; planning \& design (P\&D), construction, operation, maintenance and end-of-life (EOL). The selected units were developed in a virtual environment using building information modelling (BIM). The case studies included detached, semi-detached and terraced type housing units. The following has been concluded:

- The average contribution range remained from 148 tons- $\mathrm{CO}_{2}$ to 284 ton- $\mathrm{CO}_{2}$ for the design life of 100 years;

- The execution phase contributed the most in almost all the cases with a share of $42.70 \%$ followed by the operation phase with an average contribution of $39 \%$, the maintenance phase $(15 \%)$, planning \& design phase $(1.8 \%)$ and dismantling and dispose-off (1.60\%) remained at the bottom of list;

- As the design life varied with an interval of almost $20 \%$ to $10 \%$ (50 to 60 to 70 to 80 to 90 to $100 y r s$.), the corresponding carbon footprint increased by $8.46 \%, 9.88 \%$, $7.08 \%, 5.77 \%$ and $7.96 \%$ for each to the respective time interval.

The overall change for 50-year-time interval worked out nearly $50 \%$. The duration of operational phase in whole project life cycle was more than $95 \%$, however, its emission contribution remained almost $10 \%$ less than embodied category. A significant positive relationship between the dependent (carbon foot print) and independent variable (area) was observed. The physical design features were important factor in variance of environmental effects.

\section{ACKNOWLEDGEMENT}

The authors acknowledge the support of CUST, Islamabad Pakistan and UTP, Malaysia for successful completion of this study. The authors would also like to thank the organizations, industrial practitioners who have provided their valuable feedback in this research.

\section{REFERENCES}

[1] IPCC. Climate change 2007: synthesis report. Contribution of working groups I, II and III to the Fourth Assessment Report of the Intergovernmental Panel on Climate Change. Geneva: IPCC, 2007.

[2] Safaai N. S. M., et al. Projection of $\mathrm{CO}_{2}$ emissions in Malaysia. Environmental Progress \& Sustainable Energy 2010:30(4):658-665. https://doi.org/10.1002/ep.10512

[3] Chakraborty S., Tiedemann A., Teng P. Climate change: potential impact on plant diseases. Environmental Pollution 2000:108(3):317-326. https://doi.org/10.1016/S0269-7491(99)00210-9

[4] Spence C. Global warming: Personal solutions for a healthy planet. London: Palgrave Macmillan, 2005.

[5] Ortiz-Rodríguez O., Castells F., Sonnemann G. Life cycle assessment of two dwellings: One in Spain, a developed country, and one in Colombia, a country under development. Science of The Total Environment 2010:408(12):23452443. https://doi.org/10.1016/j.scitotenv.2010.02.021

[6] Banihashemi S., et al. Optimization of environmental impacts of construction projects: a time-cost-quality trade-off approach. International Journal of Environmental Science and Technology 202:18:631-464. https://doi.org/10.1007/s13762-020-02838-2

[7] San-José Lombera J.-T., Cuadrado Rojo J. Industrial building design stage based on a system approach to their environmental sustainability. Construction and Building Materials 2010:24(4):438-447. https://doi.org/10.1016/i.conbuildmat.2009.10.019

[8] Department for Business, Innovation and Skills. Low Carbon Construction Innovation \& Growth Team. Final Report. London: BIS, 2010.

[9] Singh A., et al. Review of life-cycle assessment applications in building construction. Journal of Architectural Engineering 2010:17(1):15-23.

[10] Kua H. W., Wong C. L. Analysing the life cycle greenhouse gas emission and energy consumption of a multi-storied commercial building in Singapore from an extended system boundary perspective. Energy and Buildings 2012:51:614. https://doi.org/10.1016/j.enbuild.2012.03.027

[11] Hallberg D., Tarandi V. On the use of open bim and 4d visualisation in a predictive life cycle management system for construction works Journal of Information Technology in Construction 2011:16:445-466. 
[12] McAuley B., Hore A. V., West R. Use of Building Information Modelling in Responding to Low Carbon Construction Innovations: an Irish Perspective. Proceedings of the International Conference on Management of Construction: Research to Practice 2012:6.

[13] Acquaye A. A., Duffy A. P. Input-output analysis of Irish construction sector greenhouse gas emissions. Building and Environment 2010:45(3):784-791. https://doi.org/10.1016/j.buildenv.2009.08.022

[14] Liu S., et al. Optimizing cost and $\mathrm{CO}_{2}$ emission for construction projects using particle swarm optimization. Habitat International 2013:37:155-162. https://doi.org/10.1016/j.habitatint.2011.12.012

[15] Rosselló-Batle B., et al. Energy use, $\mathrm{CO}_{2}$ emissions and waste throughout the life cycle of a sample of hotels in the Balearic Islands. Energy and Buildings 2010:42(4):547-558. https://doi.org/10.1016/j.enbuild.2009.10.024

[16] Tsai W.-H., et al. Incorporating life cycle assessments into building project decision-making: An energy consumption and $\mathrm{CO}_{2}$ emission perspective. Energy 2011:36(5):3022-3029. https://doi.org/10.1016/j.energy.2011.02.046

[17] Nässén J., et al. Direct and indirect energy use and carbon emissions in the production phase of buildings: an inputoutput analysis. Energy 2007:32(9):1593-1602. https://doi.org/10.1016/j.energy.2007.01.002

[18] Chang Y., Ries R. J., Wang Y. The embodied energy and environmental emissions of construction projects in China: An economic input-output LCA model. Energy Policy 2011:38(11):6597-6603. https://doi.org/10.1016/j.enpol.2010.06.030

[19] ELAW. National Environment Agency, Singapore's National Climate Change Strategy. Eugene: ELAW, 2008.

[20] Atmaca A. Life cycle assessment and cost analysis of residential buildings in south east of Turkey: part 1-review and methodology. The International Journal of Life Cycle Assessment 2016:21(6):831-846. https://doi.org/10.1007/s11367016-1050-8

[21] Razali N., et al. Carbon footprint assessment of machinery usage: Case study on hostel construction in Perlis, Malaysia. Proceedings of the International Conference on Sustainable Energy \& Environmental Sciences 2016:18-22. https://doi.org/10.5176/2251-189X_SEES16.9.

[22] Ramesh T., et al. Life cycle energy analysis of buildings: An overview. Energy and Buildings 2010:42(10):1592-1600. https://doi.org/10.1016/j.enbuild.2010.05.007

[23] Tiwari P. Energy efficiency and building construction in India. Building and Environment 2001:36(10):1127-1135. https://doi.org/10.1016/S0360-1323(00)00056-1

[24] Lu M., Lai J. Review on carbon emissions of commercial buildings. Renewable and Sustainable Energy Reviews 2020:119:109545. https://doi.org/10.1016/j.rser.2019.109545

[25] Nematchoua M. K., Reiter S. Net Zero Energy Buildings and Low Carbon Emission, a Case of Study of Madagascar Island. Sustainable Building Materials. London: IntechOpen, 2020.

[26] Zuo J., et al. Achieving carbon neutrality in commercial building developments-Perceptions of the construction industry. Habitat International 2012:36(2):278-286. https://doi.org/10.1016/j.habitatint.2011.10.010

[27] . Dixit M. K, et al. Need for an embodied energy measurement protocol for buildings: A review paper. Renewable and Sustainable Energy Reviews 2012:16(6):3730-3743. https://doi.org/10.1016/j.rser.2012.03.021

[28] Yeheyis M., et al. An overview of construction and demolition waste management in Canada: a lifecycle analysis approach to sustainability. Clean Technologies and Environmental Policy 2013:15(1):81-91. https://doi.org/10.1007/s10098-012-0481-6

[29] Abbasizade F., et al. An innovative executive and financial mechanism for energy conservation in new and existing buildings in Iran. International Journal of Environmental Science and Technology 2020:17:4217-4232. https://doi.org/10.1007/s13762-020-02728-7

[30] Chang Y., Ries R. J., Wang Y. The quantification of the embodied impacts of construction projects on energy, environment, and society based on I-O LCA. Energy Policy 2011:39(10):6321-6330. https://doi.org/10.1016/j.enpol.2011.07.033

[31] Azapagic A. Life cycle assessment and its application to process selection, design and optimisation. Chemical Engineering Journal 1999:73(1):1-21. https://doi.org/10.1016/S1385-8947(99)00042-X

[32] Moon H., Hyun C., Hong T. Prediction Model of $\mathrm{CO}_{2}$ Emission for Residential Buildings in South Korea. Journal of Management in Engineering 2014:30(3):04014001. https://doi.org/10.1061/(ASCE)ME.1943-5479.0000228

[33] Buyle M., Braet J., Audenaert A. Life cycle assessment in the construction sector: A review. Renewable and Sustainable Energy Reviews 2013:26:379-388. https://doi.org/10.1016/j.rser.2013.05.001

[34] Asdrubali F., Baldassarri C., Fthenakis V. Life cycle analysis in the construction sector: Guiding the optimization of conventional Italian buildings. Energy and Buildings 2013:64:73-89. https://doi.org/10.1016/j.enbuild.2013.04.018

[35] Huang Y., Niu J.-L., Chung T.-M. Energy and carbon emission payback analysis for energy-efficient retrofitting in buildings - Overhang shading option. Energy and Buildings 2012:44:94-103. https://doi.org/10.1016/j.enbuild.2011.10.027

[36] Pacheco-Torres R., et al. Analysis of $\mathrm{CO}_{2}$ emissions in the construction phase of single-family detached houses. Sustainable Cities and Society 2014:12:63-68. https://doi.org/10.1016/j.scs.2014.01.003

[37] Proietti S., et al. Life Cycle Assessment of a passive house in a seismic temperate zone. Energy and Buildings 2013:64:463-472. https://doi.org/10.1016/j.enbuild.2013.05.013 
[38] Ghose A., et al. Refurbishment of office buildings in New Zealand: identifying priorities for reducing environmental impacts. The International Journal of Life Cycle Assessment 2019:24(8):1480-1495. https://doi.org/10.1007/s11367$018-1570-5$

[39] Arvizu-Piña V. A., Cuchí-Burgos A., Barrera-Alarcón I. G. A top-down approach for implementation of Environmental Product Declarations in Mexico's housing sector. The International Journal of Life Cycle Assessment 2020:25(1):157167. https://doi.org/10.1007/s11367-019-01657-z

[40] Nasab T. J., et al. Assessment of carbon footprint in the construction phase of high-rise constructions in Tehran. International Journal of Environmental Science and Technology 2019:17:3153-3164. https://doi.org/10.1007/s13762019-02557-3

[41] Castell A., et al. Life Cycle Assessment of alveolar brick construction system incorporating phase change materials (PCMs). Applied Energy 2013:101:600-608. https://doi.org/10.1016/j.apenergy.2012.06.066

[42] Sharma A., et al. Life cycle assessment of buildings: a review. Renewable and Sustainable Energy Reviews 2011:15(1):871-875. https://doi.org/10.1016/j.rser.2010.09.008

[43] Mafimisebi B. I., et al. Procedural tool for analysing building energy performance: structural equation modelling protocol. International Journal of Environmental Science and Technology 2020:17:2875-2888. https://doi.org/10.1007/s13762-020-02708-x

[44] National Institute of Building Sciences. National building information modeling standard; Version 1 - Part 1: Overview, Principles and Methodologies. Washington: National Institute of Building Sciences, 2007.

[45] ISO-14040: Environmental management-life cycle assessment-principles and framework. London: British Standards Institution, 2006.

[46] Hammond G., et al. Embodied carbon: the inventory of carbon and energy (ICE). Bracknell: BSRIA, 2011.

[47] AEA. 2012 Guidelines to Defra / DECC's GHG Conversion Factors for Company Reporting. Nashville: AEA, 2012.

[48] Huberman N., Pearlmutter D. A life-cycle energy analysis of building materials in the Negev desert. Energy and Buildings 2008:40(5):837-878. https://doi.org/10.1016/j.enbuild.2007.06.002

[49] Department of Statistics Malaysia. Household Income and Basic Amenities Survey 2014. Putrajaya: DoSM, 2015.

[50] Energy Commission. Malaysia Energy Statistics Handbook. Malaysia: Energy Commission, 2014.

[51] International Energy Agency. $\mathrm{CO}_{2}$ Emissions from Fuel Consumptions. Paris: IEA, 2015.

[52] Mithraratne N., Vale B. Life cycle analysis model for New Zealand houses. Building and Environment 2004:39(4):483492. https://doi.org/10.1016/j.buildenv.2003.09.008

[53] DCA Office of Affordable Housing. Architectural Manual 2011, Expected Useful Life Table. Washington: DCA, 2011.

[54] Kellenberger D., Althaus H.-J. Relevance of simplifications in LCA of building components. Building and Environment 2009:44(4):818-825. https://doi.org/10.1016/j.buildenv.2008.06.002 